\title{
COMPARATIVE STUDY OF THE UDDER STRUCTURE IN BUFFALOES AND CATTLE: 2-HISTOLOGICAL CONSTITUTION OF THE MAMMARY TISSUE ${ }^{*}$
}

\author{
Safaa S. El-Ghousien ${ }^{1}$, M. M. Shafie ${ }^{2}$, G. Ashour ${ }^{2}$, and A. L. Badreldin ${ }^{2}$
}

1- Faculty of Agriculture and Science, Jerash Private University, Jerash, Jordan

2- Department of Animal Production, Faculty of Agriculture, Cairo University, Giza, Egypt

\section{SUMMARY}

Six udders, 2 from each of Egyptian buffaloes and cattle and Friesian, one at early lactation and one at late lactation were used to study the histological constitution of the udder. The animals were slaughtered, without milking, and the udders were separated and hardened in formol-saline. Surface and internal samples (about $2 \mathrm{~cm}^{3}$ ) from each quarter of the udder were taken for micro-histological studies. The histological studies were; teat structure, the average of mammary gland lobular parenchyma and interlobe, connective tissue areas in the cross sections alongside alveoli density, average circumference, diameter, volume and surface area of alveolus. The mean number, total surface and volume of alveoli in $\mathrm{cm}^{2}$ and $\mathrm{cm}^{3}$ of the general gland tissue and lobar tissue were calculated. The teat (canal and muscles) had the same general structure in all the animals. At early lactation, the ratio of the glandular parenchyma tissue to connective tissue were 4.0:1 in buffaloes, 1.5:1 in Egyptian cattle and 2.5:1 in Friesian. The average diameter of alveoli was; 151, 101 and 99 micron in the three categories, respectively. The number of alveoli/ $\mathrm{cm}^{3}$ of the mammary tissue in the cattle breeds were double that in buffaloes. Correlation coefficients between the volume and number of alveoli per $1 \mathrm{~cm}^{3}$ were 0.85, 0.77 and 0.88 in buffaloes, Friesian and Egyptian cattle, respectively. The total volume and total surface area of alveoli in $/ 1 \mathrm{~cm}^{3}$ of the gland tissue were larger in Friesian than in the other breeds. It could be concluded that the total volume and surface area of alveoli conform with difference in milk production between species and breeds.

Keywords : Udder, mammary glands, buffaloes, cattle

\section{INTRODUCTION}

The udder of the bovines comprise four mammary glands, each occupying one quarter. The glands have similar principal histological features which show proportional micro-morphometric changes during gestation and lactation stages. The general makeup of the histological structure comprise two types of tissues: 1) The parenchyma (secretory epithelium) arranged in racemose lobe-lobular structure. 2)

${ }^{*}$ This paper was presented in the $53^{\text {rd }}$ Annual Meeting of the European Association for Animal Production (as an abstract).

Issued by The Egyptian Society of Animal Production 
Connective tissue, intervening the parenchyma. A desirable udder should contain a minimal amount of connective tissue and a maximal amount of secretory tissue. Although, species and breed of bovines possess this basic structure yet they vary in the extent of the ratio parenchyma : connective tissues. The dairy cattle breeds are expected to have greater ratio irrespective of the level of physiological activity of milk secretion. Hunold (1959) reported that with increasing yield of milk and fat there was a relative increase in the percentage of parenchyma with a corresponding decline in connective tissue. Krastev and Konev (1963) found, in Rhodope cattle, the parenchyma \% was 85 . Solov' eva (1964) reported that the ratio Paren. : Conn. in Black Pied cattle was 5.9:1 before milking compared with 1.7:1 after milking. Bychkov (1971) determined daily milk yield and some udder characteristics in high yielding cows sacrificed at the $3^{\text {rd }}, 7^{\text {th }}$ and $10^{\text {th }}$ mon. of lactation. He reported the following values respectively; milk yield $13.5,8.2$ and $4.1 \mathrm{Kg}$, secretory tissue \% 67.2, 60.5 and 55.0, alveolar diameter 95.8, 66.0 and 33.0 micron.

Hassan (1994) and Hassan et al. (1995 a and b) reported that the percentage of sectional area of parenchyma in sections of biopsy taken from Egyptian buffaloes at successive stages of lactation were $66.36,84.48$ and $60.58 \%$, at 7 days, 35 days and 5 mon. (late lactation).

The present work was carried to compare the general histological feature of the mammary glands of Friesian, Egyptian cattle and Egyptian buffaloes, at two stages of lactation, early and late stages.

\section{MATERIALS AND METHODS}

This work was carried out in the Faculty of Agriculture, Cairo University, Egypt. The study was executed on two udders from each of Friesian, Egyptian buffaloes and cattle. One udder was at early lactation while the other was at late lactation, the criteria of the used udders are shown below:

Criteria of the udders used in the study at early (EL) and late (LL) lactation

\begin{tabular}{lccccc}
\hline Breed & Parity & $\begin{array}{c}\text { Lactation } \\
\text { Stage (mon.) }\end{array}$ & $\begin{array}{c}\text { Daily milk } \\
\text { yield }\end{array}$ & $\begin{array}{c}\text { Body weight } \\
(\mathbf{k g})\end{array}$ & $\begin{array}{c}\text { Udder weight } \\
(\mathbf{k g})\end{array}$ \\
\hline $\begin{array}{c}\text { Friesian } \\
\text { EL }\end{array}$ & 4 & 2.0 & 7.0 & 310 & 7.5 \\
$\quad$ LL & 4 & 9.0 & 3.0 & 320 & 5.7 \\
E. Cattle & & & & & \\
$\quad$ EL & 3 & 1.5 & 4.0 & 330 & 9.7 \\
LL & 3 & 9.0 & 3.5 & 355 & 7.6 \\
Buffaloes & & & & & \\
EL & 3 & 0.5 & 7.0 & 468 & 14.8 \\
LL & 3 & 8.0 & 4.5 & 370 & 8.1 \\
\hline
\end{tabular}

"Within a week before slaughter.

Each udder was detached completely just after slaughtering the cow, without milking, for anatomical study (El-Ghousien et al., 2002) and this histological study. 


\section{Histological technique :}

From each quarter 2 samples (about $2 \mathrm{~cm}^{3}$ ) were collected from its mammary gland, one from the surface just under the outer ligament (surface region) while the other was obtained from the central region. From the teats, samples were cut off at the tip and others crossing the teat (streak) canal. Each sample was fixed in $10 \%$ formol saline for $24 \mathrm{hrs}$. The successive procedure of general histological technique was followed till embedding in parafin wax. Sections at 5 mic. were stained by hematoxlin-eosin method and mounted in canada balsam. The histological constitutions of the mammary tissue were identified and measured by morphometric techniques on microprojection images. The teat sections were studied microscopically.

\section{Morphometric measurements :}

The percentage of parenchyma area and area of connective tissue were obtained from the image of the microprojections by the relative weight values of the paper areas occupied by each component as described by Oshima and Gota (1955). Five images for each tissue sample sections were obtained. The boundaries of the parenchyma areas were outlined in each image (Figure 1) then cut and weighed to get the total areas of parenchyma in each image. The connective tissue area was obtained by the difference of the total of parenchyma areas from the whole area of the image $\left(60 \mathrm{~cm}\right.$ diameter, $\left.5.7 \mathrm{~mm}^{2}\right)$. The total number of alveoli in each image of these fields was obtained by counting the alveoli in each parenchyma area and added to have the total count per field.

A similar procedure was followed to obtain the concentration (No.) of alveoli in the parenchyma tissue, in 12 microscopical fields $\left(0.1 \mathrm{~mm}^{2}\right)$ each field was projected into image of $20 \mathrm{~cm}$ diameter. The circumference of 10 alveoli in each field was measured by a curvimeter to estimate the average diameter, volume, and surface area per each alveolus.

\section{RESULTS AND DISCUSSION}

\section{Histological constituents of the udder:}

\section{1- Teat :}

The teat had the same general structure in all animals. The stroma was strongly rich in blood vessels and capillaries. The main arteries appeared exceptionally conspicuous in that exclusively peripheral organ. A similar structure was reported in Indian buffaloes by Uppal et al. (1995). 

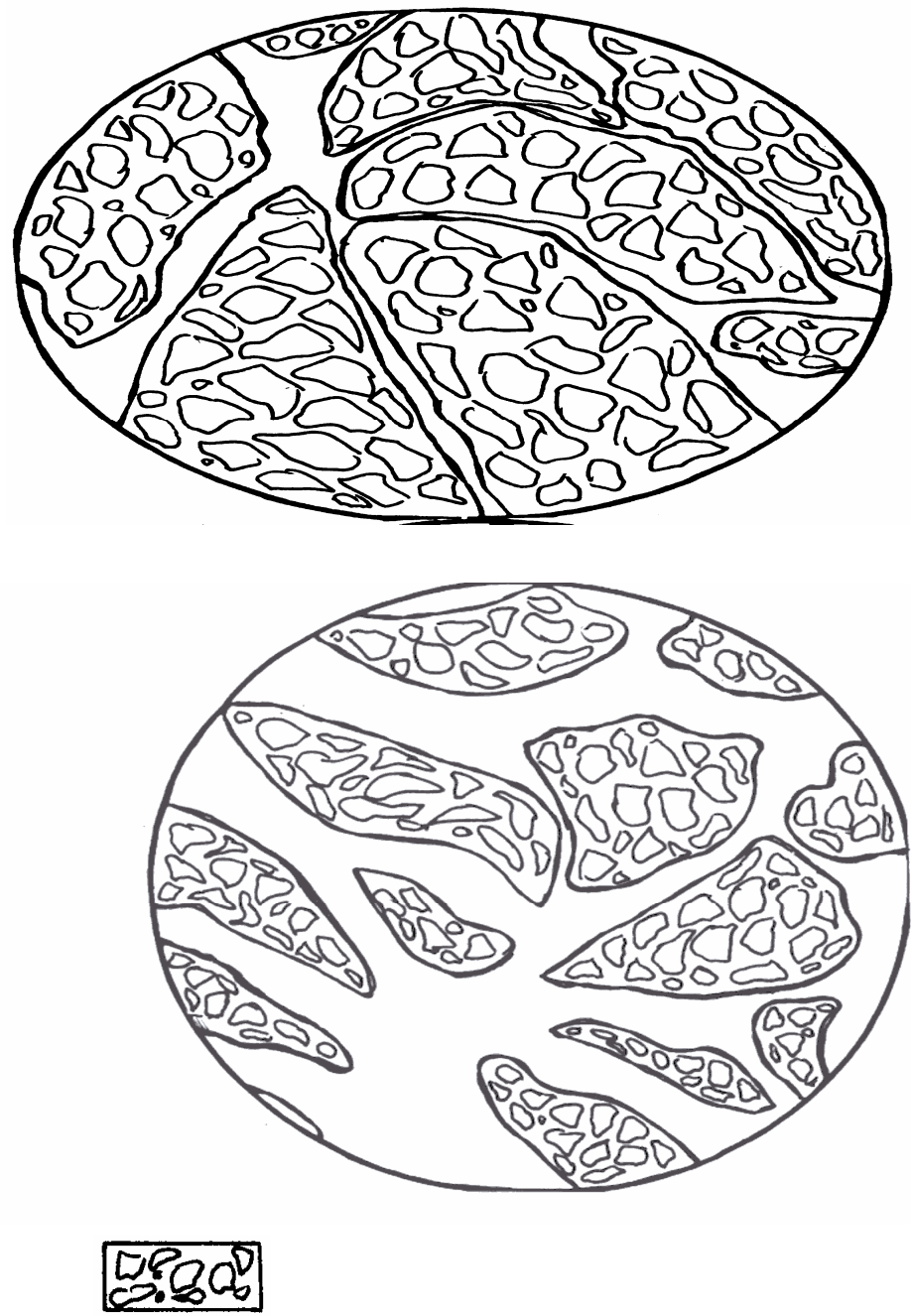

Parenchyma

Figure 1. Technical method of determining the total sectional area of parenchyma in microprojected image of microscopic section 


\section{1- Teat canal (Streak canal) :}

The teat canal was surrounded by thick papillated stratified epithelial tissue. The cornifield layer surrounding the lumen was strongly thick showing signs of pealing and replacement (Plate 1). The cornification is a good structural adaptation to the mechanical friction of milk flow during milking and suckling. This thick cornium layer could also provide a protection against the invasion of microorganisms through the orifice of the teat. The muscles of the teat showed a general feature in all the animals. The tip of the teat was devoid of muscles (Plate 2), just above the tip, 2 mm., circular muscle bundles appeared encircling the epithelium of the canal. This muscular setup forms the sphincter which surrounds the whole length of the canal (Plate 3). At scattered zones longitudinal muscle bundles pierce the circular muscles (Plate 4), towards the canal, thus forming radial arrangement which enforces the function of the sphincter .

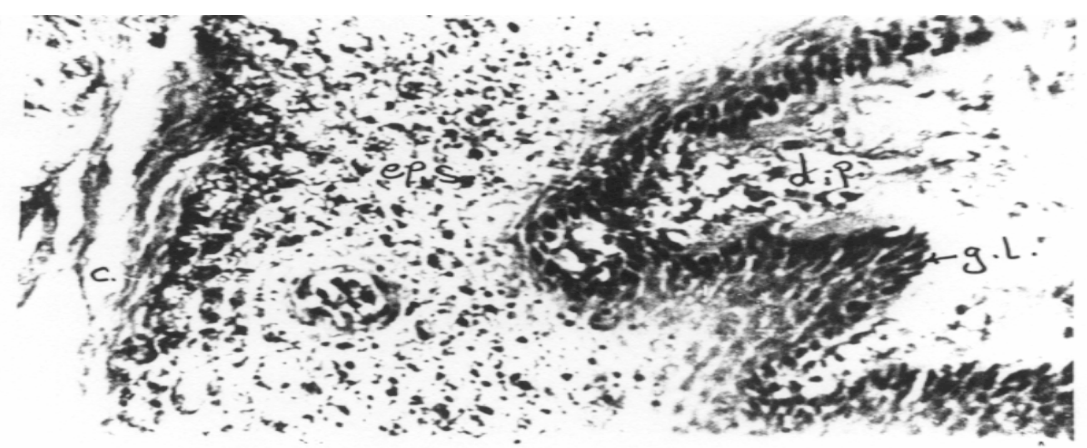

Plate 1. Papillated stratified epithelium with cornfied layer surrounding the lumen of teat canal (X 135).

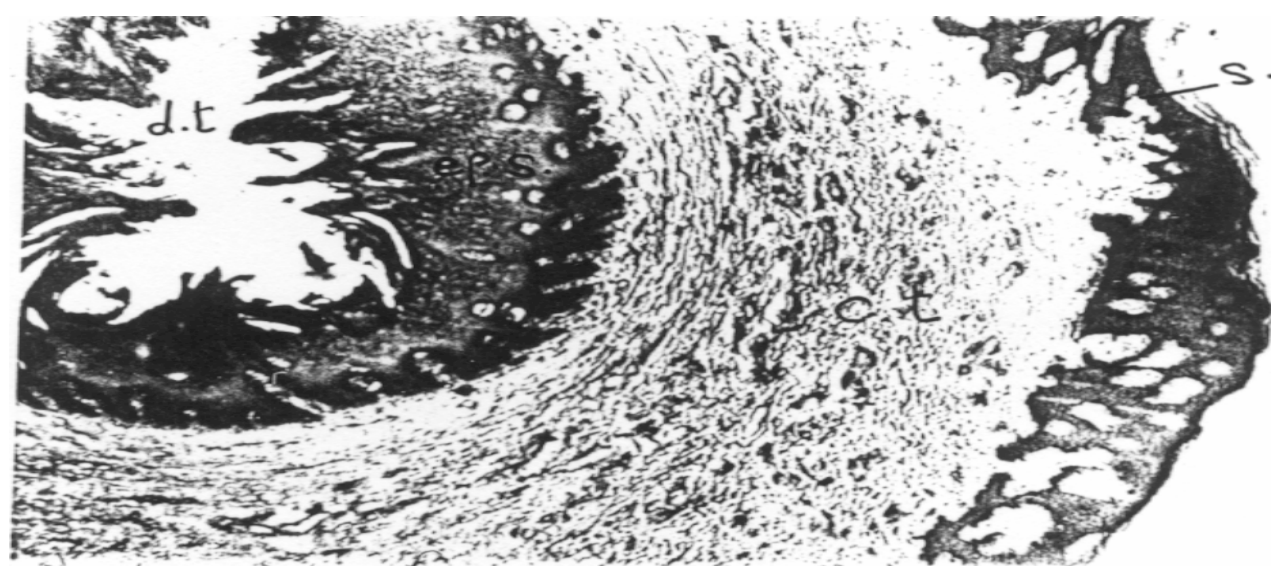

Plate 2. The tip of the teat devoid of muscles (X21). 


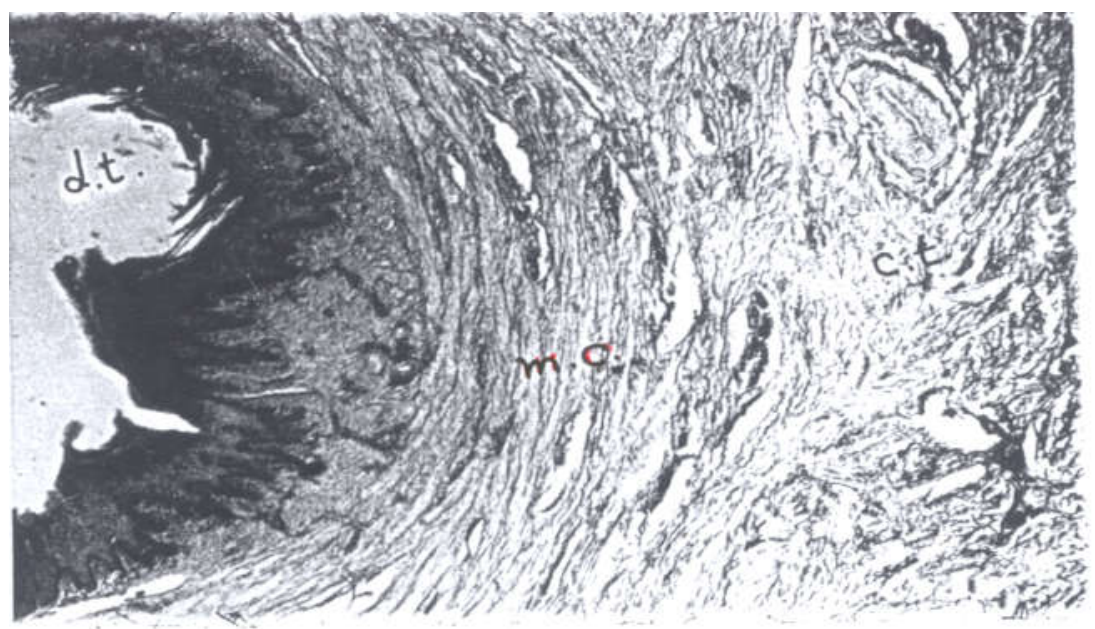

Plate 3. Muscles forming sphincter surrounding the whole length of teat canal (X 60).

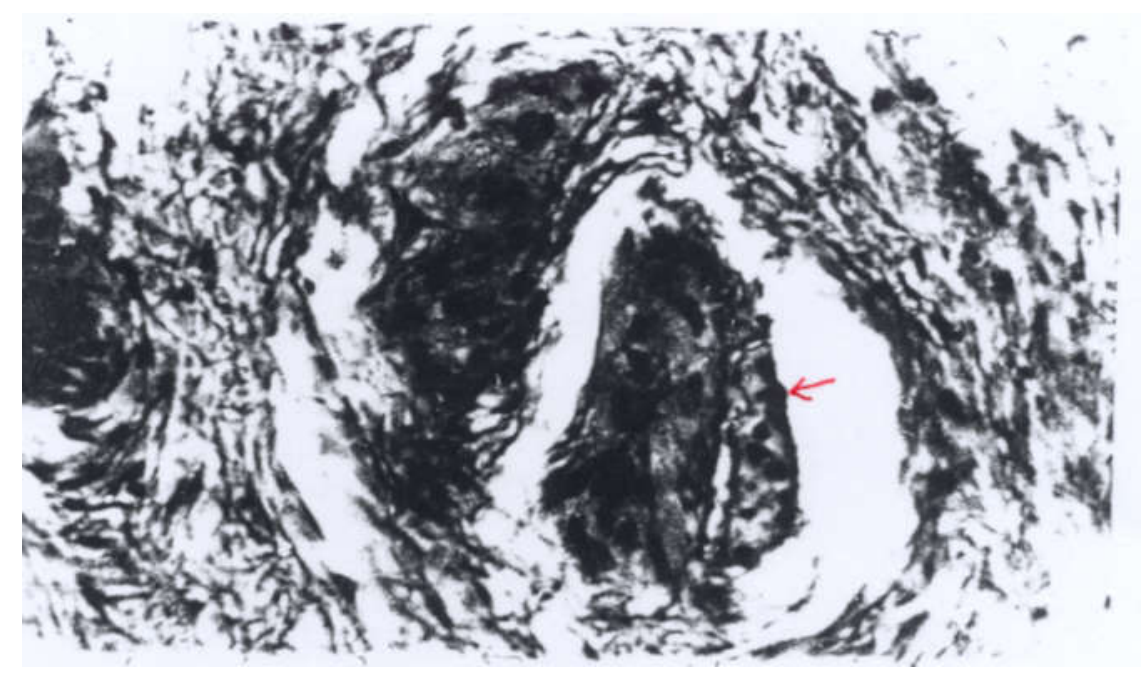

Plate 4. Longitudinal muscle bundles (shown by) piercing the circular muscles sphincter of the teat canal (X 270). 


\section{2- Teat cistern :}

The lumen of the teat cistern was legend by two layers of epithelial cells. In the cross sections, the epithelium appeared as a regular ring in buffaloes and Friesian, while in the Egyptian cattle it was corrugated giving astric appearance to the cross sectional area of the lumen (Plate 5). These corrugations in the lining of the cistern in Egyptian cattle seems to permit increase in the cistern volume during milking. Bundles of smooth muscles spread in different directions around the cistern at different levels and depths in the stroma of the teat (Plate 6).

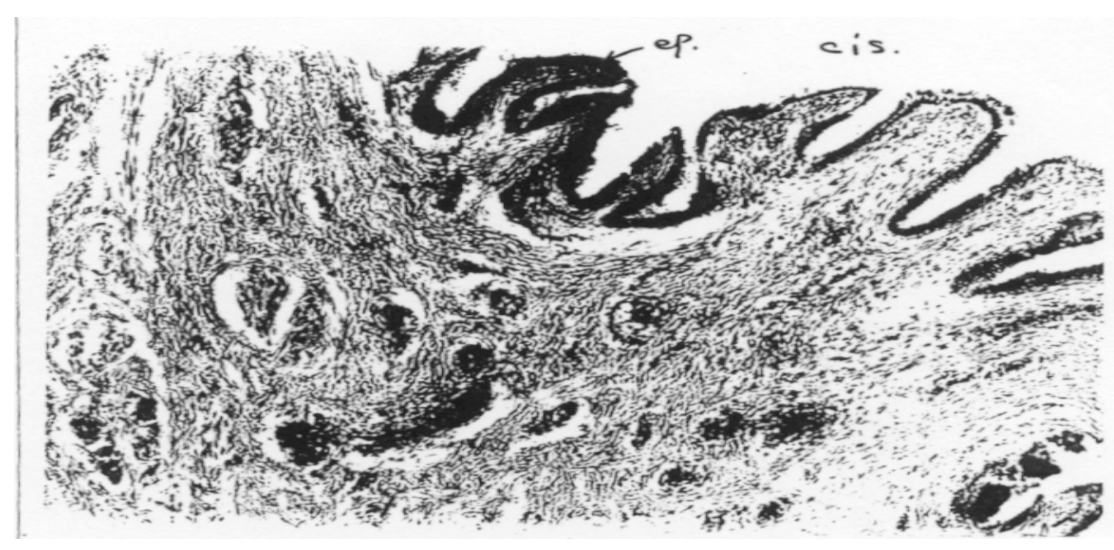

Plate 5. Epithelium of the teat cistern corregated giving asteric appearance to the cross sectional area of the lumen (X 60).

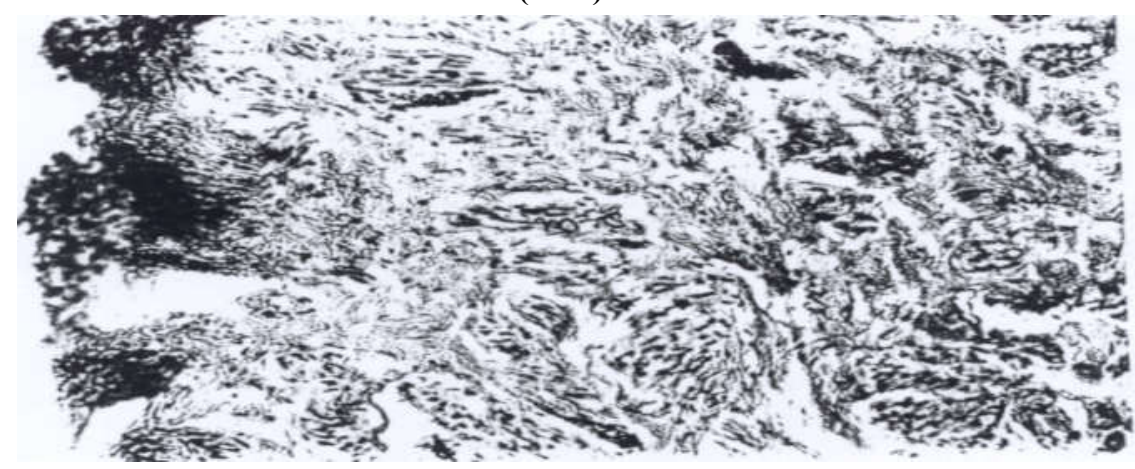

Plate 6. Bundles of circular muscles spreading around the teat cistern at different levels in the stroma, in E. cattle (X 60).

\section{2- Glandular tissue :}

The sections of the glandular tissue showed the general picture of the mammary glands, that the entire gland is composed of a great number of lobes separated by thick connective tissue each being drained by a single duct (Plate 7). The main blood vessels branches appeared clearly through this interlobar connective tissue (Plates 8 and 9). This fibrous interlobar connective tissue provided thin septa which branched 
inside the lobe and divided its mass into numerous lobules (Plates 7 and 8). The lobules were composed of alveoli separated by thin connective tissue septa. Each lobule had a main duct, the lobular duct, which drains in the main lobar duct (Plate 7). The alveoli were mostly globular in shape (Plates 7, 8 and 10). Starting the involution of the gland enhanced, near to the end of lactation, the parenchymatous tissue, alveoli, lobules and lobes shrinked giving space to the expanding space of connective tissue inside and surrounding the lobules and lobes (Plate 10). In some cases fat cells were abundant in the interlobular areas. This case was not clear in Friesian while in Egyptian cattle it appeared in both cases at early and late lactation (Plate 11). Buffaloes showed some fat cells clusters only near to the end of lactation.

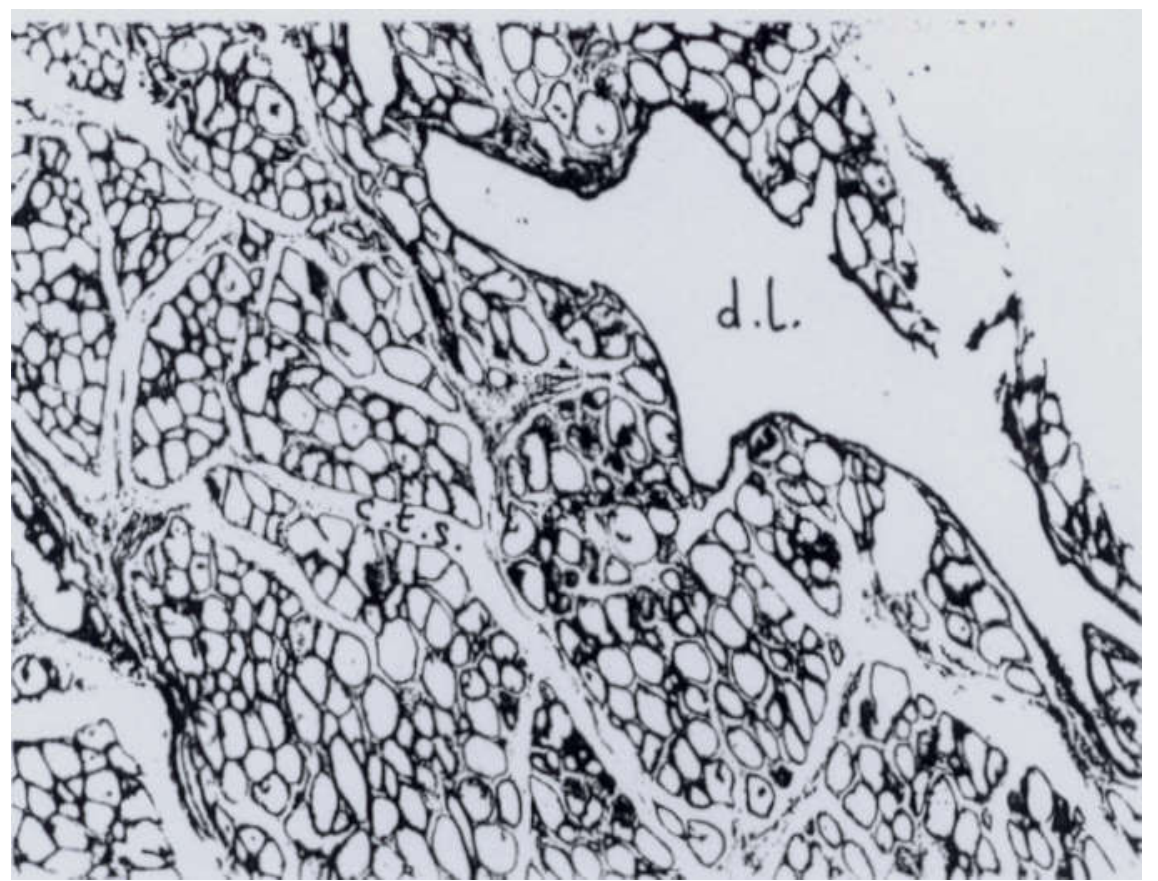

Plate 7. Mammary gland lobe segmented to lobules with main lobe duct (X 21). 


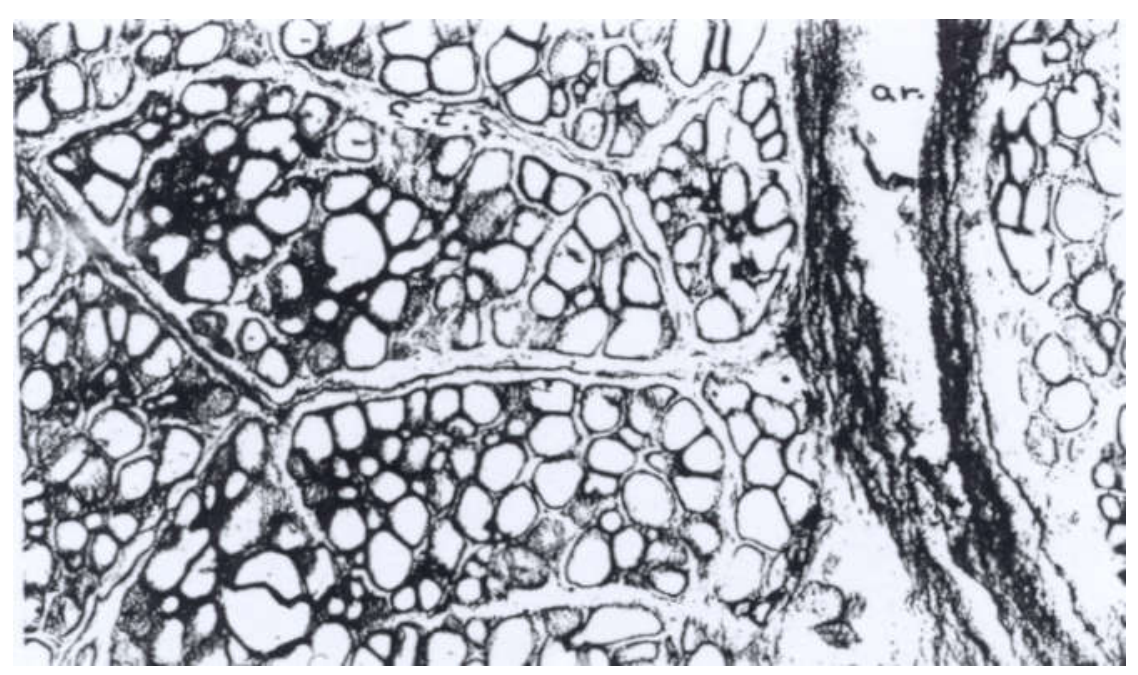

Plate 8. Mammary gland lobules and artery in the interlobar connective tissue (X 21).

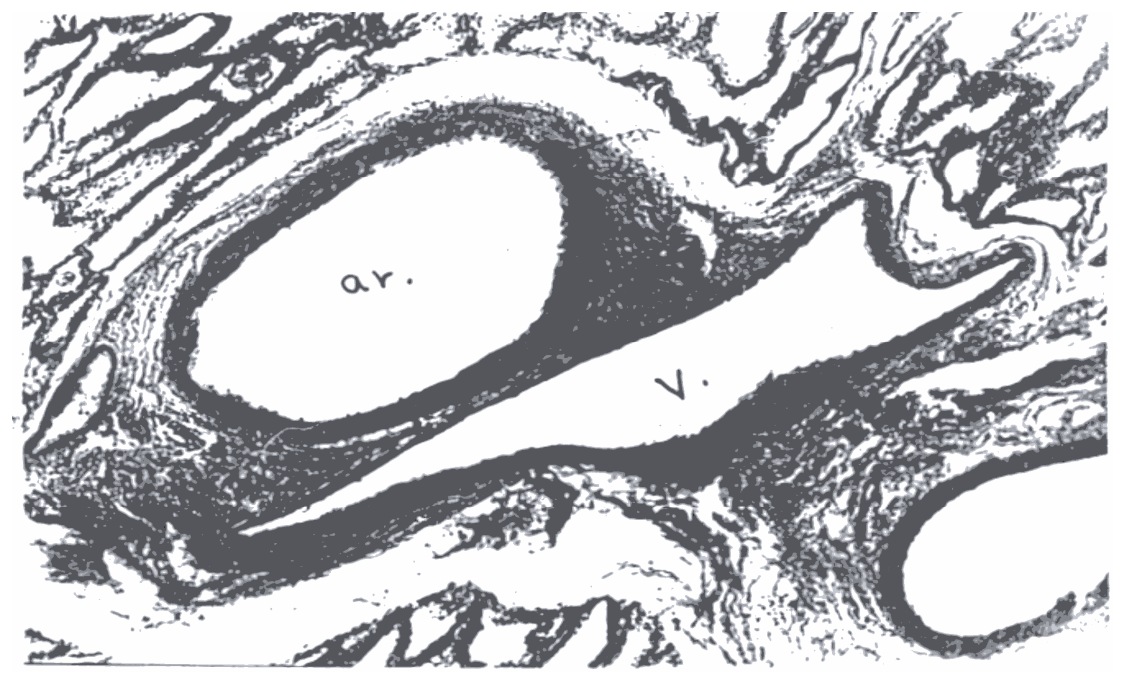

Plate 9. Main blood vessels artery (ar.) and vein (v.) in the connective tissue of the mammary gland (X 60). 


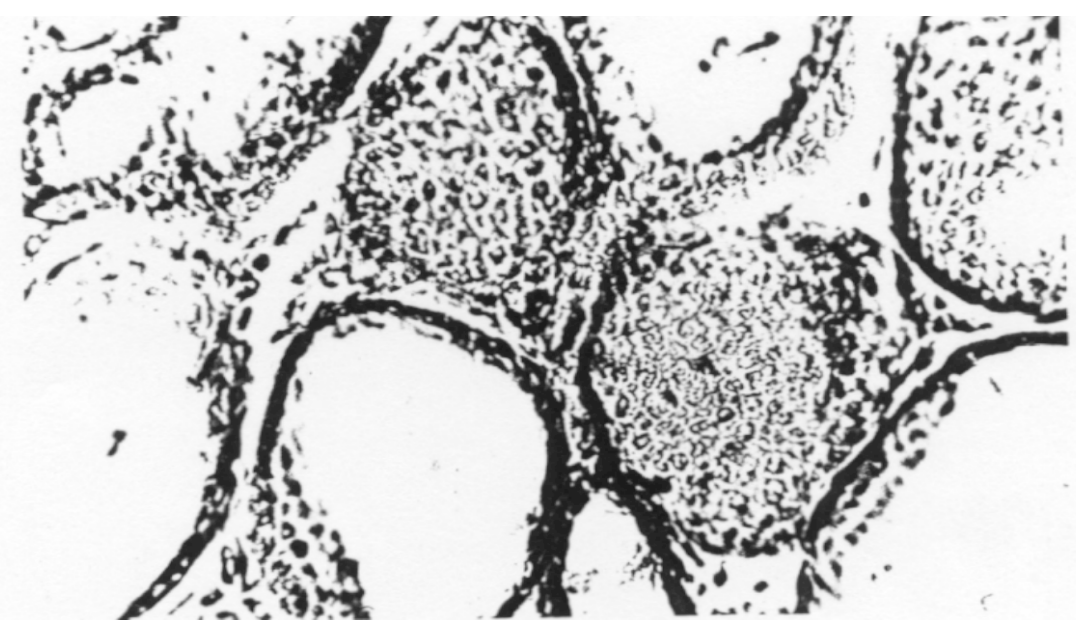

Plate 10. Sections and surface view of the alveoli in the mammary gland (X135).

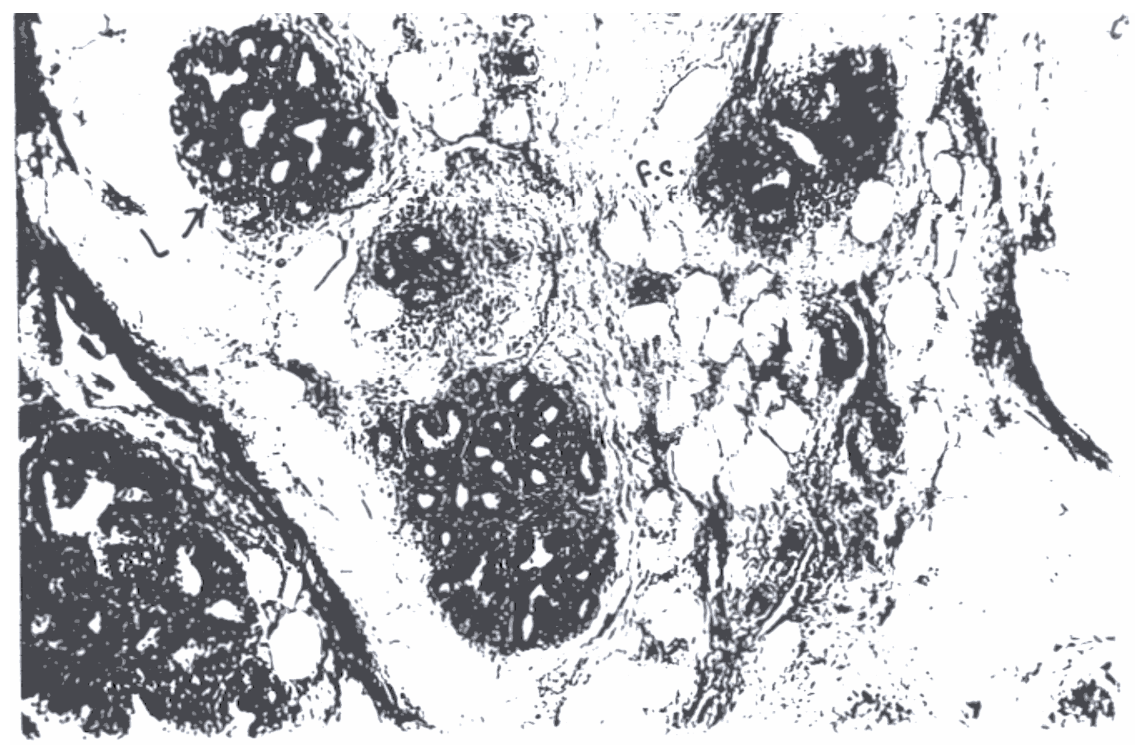

Plate 11. Clusters of fat cells in the connective tissue at late lactation in E. cattle (X 60). 


\section{Parenchyma : connective tissue ratio :}

Table 1 shows the percentage sectional area occupied by parenchyma in sections of mammary tissue of the studied udders. It is clear that buffaloes acquired the greatest average of this parenchyma area percentage ( 80.5 and 74.5 at early and late lactation) followed by Friesian (70.8 and 74.8\%, respectively). The Egyptian cattle possessed the least parenchyma percentage (58.8 and $60.7 \%$, respectively). The cattle breeds, particularly Friesian, showed greater average value at late lactation than at early lactation while buffaloes showed an opposite case. This denotes that the shrinkage of the udder size during involution (late lactation) involves the inter lobar connective tissue in cattle while the opposite occurred in buffaloes. The connective tissue occupies the complementary percentage to the parenchyma, so that the ratio parenchyma : Connective tissue gives good comprehension of the lactation capacity of the studied udder (Table 2).

The percentage of parenchyma in each of the udder quarters had similar values very close to the total udder average in the three species (Table 3 ).

\section{Alveoli traits : \\ Density:}

Table 4 includes the means and averages of the alveoli density, number of alveoli as counted per sectional area $\left(5.7 \mathrm{~mm}^{2}\right)$ of microprojected image of the mammary tissue from the quarters of the studied udders. Table (5) presents the numbers of the alveoli in $0.1 \mathrm{~mm}^{2}$ sectional area in the parenchyma tissue.

\section{Size parameters:}

Table 6 presents the alveoli circumference values (micron) measured coincidentally in the parenchyma with its density in the microprojected image. The general averages in Table 6 shows that Friesian retained comparable sizes allover the lactation period (early till late lactation) while buffaloes showed great reduction in alveoli size at late lactation. This case of size reduction (38\%) in buffaloes is opposite to the increase in density (Table 5) by $87 \%$ at (LL). Does this suggest that involution proceeds in buffaloes mainly by shrinkage of alveoli while in Friesian mainly by reduction in number? Wilde et al. (1997) concluded that termination of lactation of bovine was associated with partial loss of the mammary cells population and differentiation of the remainder. In all the cases there was negative relationship between the density and volume of alveoli. The correlation coefficients (Table 7) were significant in 13 cases in Friesian vs. 11 in Egyptian cattle and 9 in buffaloes. This species difference needs further investigation-by biopsy-in greater number of animals and successive stages throughout the lactation curve.

The circumference value of each measured alveolus was utilized to calculate its diameter, volume and surface area and compute the mean values for each case and the general average of the animals at lactation stages. Table (8) includes the general averages of alveoli parameters. The diameter and volume indicate the thickness of the alveolus wall and the volume of its cavity. Krastev and Konev (1963) stated that the mean diameter of alveoli in Rhodope cattle was 125 micron. Bychkov (1971) reported change in alveolus diameter with progress of lactation, being 95.8, 66.1 and 33.3 in high - yielding cows at the $3^{\text {rd }}, 7^{\text {th }}$ and $10^{\text {th }}$ month of lactation. Hassan (1994) and Hassan et al. (1995 a and b) found the mean diameters of alveoli (long and short as ovoidal shape) in Egyptian buffaloes as $106 \& 75$ micron at early lactation versus 61 and 44, respectively at late lactation. They reported that the mean height of 
alveolar epithelial cells was $8.75-9.21$ at early lactation versus 7.47 at late lactation. The surface area, in the present study denotes the number of cells surrounding the alveolus cavity.

Table 1. Percentage of parenchyma sectional area* in sections of the mammary tissue in udder samples of cattle breeds and buffaloes at early (EL) and late (LL) lactation stages in surface (SR) and middle (MR) regions of the four quarters

\begin{tabular}{|c|c|c|c|c|c|c|c|c|c|}
\hline \multirow{3}{*}{ Breeds } & \multicolumn{4}{|c|}{ Fore quarters } & \multicolumn{4}{|c|}{ Rear quarters } & \multirow{3}{*}{ Average } \\
\hline & \multicolumn{2}{|c|}{ Right } & \multicolumn{2}{|c|}{ Left } & \multicolumn{2}{|c|}{ Right } & \multicolumn{2}{|c|}{ Left } & \\
\hline & SR & MR & SR & MR & SR & MR & SR & MR & \\
\hline \multicolumn{10}{|l|}{ Friesian } \\
\hline EL & 50.2 & 73.0 & 86.1 & 77.4 & 78.8 & 61.0 & 68.3 & 70.1 & 70.8 \\
\hline $\mathbf{L L}$ & 74.7 & 75.4 & 42.8 & 76.3 & 82.2 & 88.0 & 75.7 & 83.1 & 74.8 \\
\hline \multicolumn{10}{|l|}{$\underline{\text { E. Cattle }}$} \\
\hline EL & 52.6 & 61.0 & 49.6 & 72.1 & 48.7 & 74.3 & 33.1 & 79.1 & 58.8 \\
\hline $\mathbf{L L}$ & 64.9 & 60.1 & 62.3 & 56.4 & 62.9 & 56.6 & 55.0 & 67.3 & 60.7 \\
\hline \multicolumn{10}{|c|}{ Buffaloes } \\
\hline EL & 81.4 & 73.1 & 88.1 & 72.2 & 91.0 & 74.9 & 90.2 & 72.9 & 80.5 \\
\hline $\mathbf{L L}$ & 76.7 & 75.5 & 65.9 & 77.7 & 71.0 & 79.2 & 65.8 & 83.9 & 74.5 \\
\hline
\end{tabular}

*Connective tissue occupies the complementary value to $100 \%$.

Table 2. General average and range of the ratio parenchyma : connective tissue sectional area of the mammary tissue in the quarters of Friesian, E. cattle and buffalo udders at early (EL) and late (LL) lactation stages

\begin{tabular}{lcc}
\hline Breeds & Average & Range \\
\hline $\begin{array}{c}\text { Friesian } \\
\text { EL }\end{array}$ & 2.4 & $1.1-3.4$ \\
LL & 3.0 & $0.8-7.3$ \\
E. Cattle & & \\
EL & 1.4 & $0.5-3.8$ \\
LL & 1.5 & $1.2-2.1$ \\
Buffaloes & & $2.6-10.1$ \\
EL & 4.1 & $1.9-5.2$ \\
LL & 2.9 &
\end{tabular}


Table 3. Average percentage of parenchyma sectional area in fore and rear quarters in udders of cattle breeds and buffaloes at early (EL) and late (LL) lactation stages

\begin{tabular}{lccc}
\hline Breeds & Fore quarter & Rear quarter & General \\
\hline$\frac{\text { Friesian }}{\mathbf{E L}}$ & 72.1 & 69.5 & 70.8 \\
$\mathbf{L L}$ & 67.1 & 82.2 & 74.8 \\
$\mathbf{E . \text { Cattle }}$ & & & \\
$\mathbf{E L}$ & 58.8 & 58.8 & 58.8 \\
$\mathbf{L L}$ & 61.0 & 60.0 & 60.7 \\
Buffaloes & & & \\
$\mathbf{E L}$ & 78.7 & 82.2 & 80.5 \\
$\mathbf{L L}$ & 74.0 & 75.0 & 74.5 \\
\hline
\end{tabular}

Table 4. Number of alveoli per field in sections of the mammary tissue in udder samples of cattle breeds and buffaloes at early (EL) and late (LL) lactation in surface (SR) and middle (MR) regions of the four quarters $\left(\right.$ Microprojected field area $=5.7 \mathrm{~mm}^{2}$ )

\begin{tabular}{|c|c|c|c|c|c|c|c|c|c|}
\hline \multirow{3}{*}{ Breeds } & \multicolumn{4}{|c|}{ Fore quarters } & \multicolumn{4}{|c|}{ Rear quarters } & \multirow{3}{*}{ Average } \\
\hline & \multicolumn{2}{|c|}{ Right } & \multicolumn{2}{|c|}{ Left } & \multicolumn{2}{|c|}{ Right } & \multicolumn{2}{|c|}{ Left } & \\
\hline & SR & MR & SR & MR & SR & MR & SR & MR & \\
\hline \multicolumn{10}{|l|}{ Friesian } \\
\hline EL & $421 \pm 24$ & $487 \pm 17$ & $641 \pm 32$ & $381 \pm 11$ & $459 \pm 22$ & $473 \pm 91$ & $639 \pm 27$ & $508 \pm 25$ & 501 \\
\hline $\mathbf{L L}$ & $369 \pm 6$ & $311 \pm 7$ & $222 \pm 8$ & $324 \pm 12$ & $449 \pm 21$ & $379 \pm 27$ & $268 \pm 16$ & $413 \pm 15$ & 342 \\
\hline \multicolumn{10}{|l|}{ E. Cattle } \\
\hline EL & $446 \pm 25$ & $335 \pm 44$ & $363 \pm 42$ & $416 \pm 19$ & $362 \pm 19$ & $384 \pm 12$ & $243 \pm 23$ & $274 \pm 23$ & 352 \\
\hline $\mathbf{L L}$ & $388 \pm 17$ & $419 \pm 30$ & $451 \pm 39$ & $417 \pm 14$ & $314 \pm 30$ & $303 \pm 17$ & $387 \pm 29$ & $439 \pm 12$ & 390 \\
\hline \multicolumn{10}{|l|}{ Buffaloes } \\
\hline EL & $266 \pm 20$ & $236 \pm 14$ & $153 \pm 13$ & $156 \pm 11$ & $239 \pm 18$ & $155 \pm 23$ & $210 \pm 10$ & $157 \pm 15$ & 197 \\
\hline $\mathbf{L L}$ & $486 \pm 7$ & $543 \pm 42$ & $376 \pm 31$ & $413 \pm 5$ & $398 \pm 19$ & $476 \pm 24$ & $493 \pm 44$ & $432 \pm 13$ & 451 \\
\hline
\end{tabular}

Computed average per $1 \mathrm{~mm}^{2}=\mathrm{F}(87.9$ and 60.0), E.C (61.8 and 68.4) and B (34.6 and 79.1) at EL and LL, respectively. 
Table 5. Number of alveoli per field in the parenchyma in sections of the mammary tissue in udder samples of cattle breeds and buffaloes at early (EL) and late (LL) lactation in surface (SR) and middle (MR) regions of the four quarters (Microprojected field area $=0.1 \mathrm{~mm}^{2}$ )

\begin{tabular}{|c|c|c|c|c|c|c|c|c|c|}
\hline \multirow{3}{*}{ Breeds } & \multicolumn{4}{|c|}{ Fore quarters } & \multicolumn{4}{|c|}{ Rear quarters } & \multirow{3}{*}{ Average } \\
\hline & \multicolumn{2}{|c|}{ Right } & \multicolumn{2}{|c|}{ Left } & \multicolumn{2}{|c|}{ Right } & \multicolumn{2}{|c|}{ Left } & \\
\hline & SR & MR & SR & MR & SR & MR & SR & MR & \\
\hline \multicolumn{10}{|l|}{ Friesian } \\
\hline EL & $16 \pm 0.8$ & $8 \pm 0.5$ & $14 \pm 0.7$ & $8 \pm 0.7$ & $9 \pm 0.6$ & $10 \pm 1.0$ & $17 \pm 0.4$ & $12 \pm 0.9$ & 11.8 \\
\hline $\mathbf{L L}$ & $9 \pm 0.9$ & $11 \pm 0.6$ & $10 \pm 0.7$ & $9 \pm 0.6$ & $12 \pm 0.5$ & $8 \pm 0.3$ & $8 \pm 0.6$ & $12 \pm 0.6$ & 9.9 \\
\hline \multicolumn{10}{|l|}{ E. Cattle } \\
\hline EL & $15 \pm 1.0$ & $8 \pm 0.6$ & $13 \pm 1.0$ & $9 \pm 0.9$ & $14 \pm 0.9$ & $12 \pm 0.5$ & $13 \pm 1.0$ & $7 \pm 0.3$ & 11.4 \\
\hline $\mathbf{L L}$ & $10 \pm 0.8$ & $13 \pm 1.0$ & $11 \pm 0.6$ & $14 \pm 0.7$ & $9 \pm 1.0$ & $12 \pm 0.7$ & $13 \pm 0.7$ & $12 \pm 0.9$ & 11.8 \\
\hline \multicolumn{10}{|c|}{ Buffaloes } \\
\hline EL & $6 \pm 1.0$ & $6 \pm 0.7$ & $7 \pm 0.8$ & $8 \pm 0.8$ & $6 \pm 0.7$ & $8 \pm 0.8$ & $6 \pm 0.5$ & $6 \pm 0.7$ & 6.6 \\
\hline $\mathbf{L L}$ & $17 \pm 1.0$ & $13 \pm 0.8$ & $11 \pm 2.0$ & $10 \pm 1.0$ & $11 \pm 1.0$ & $11 \pm 0.8$ & $15 \pm 1.0$ & $11 \pm 0.6$ & 12.4 \\
\hline
\end{tabular}

Computed average per $1 \mathrm{~mm}^{2}=\mathrm{F}$ (118 and 99), E.C (114 and 118) and B (66 and 124) at EL and LL, respectively.

Table 6. Circumference of alveolus (Mean ${ }^{*} \pm$ SE) of mammary tissue in udder samples of cattle breeds and buffaloes (micron) at early (EL) and late (LL) lactation in surface (SR) and middle (MR) regions of the four quarters

\begin{tabular}{|c|c|c|c|c|c|c|c|c|c|}
\hline \multirow{3}{*}{ Breeds } & \multicolumn{4}{|c|}{ Fore quarters } & \multicolumn{4}{|c|}{ Rear quarters } & \multirow{3}{*}{ Average } \\
\hline & \multicolumn{2}{|c|}{ Right } & \multicolumn{2}{|c|}{$\begin{array}{c}\text { Left } \\
\end{array}$} & \multicolumn{2}{|c|}{ Right } & \multicolumn{2}{|c|}{ Left } & \\
\hline & SR & MR & SR & MR & SR & MR & SR & MR & \\
\hline \multicolumn{10}{|l|}{ Friesian } \\
\hline$\overline{E L}$ & $214 \pm 4$ & $368 \pm 5$ & $295 \pm 2$ & $394 \pm 6$ & $334 \pm 3$ & $351 \pm 7$ & $266 \pm 2$ & $302 \pm 4$ & 316 \\
\hline $\mathbf{L L}$ & $338 \pm 7$ & $317 \pm 9$ & $283 \pm 5$ & $328 \pm 9$ & $274 \pm 2$ & $342 \pm 10$ & $381 \pm 9$ & $274 \pm 2$ & 317 \\
\hline \multicolumn{10}{|l|}{ E. Cattle } \\
\hline EL & $237 \pm 7$ & $368 \pm 18$ & $268 \pm 6$ & $376 \pm 8$ & $242 \pm 2$ & $278 \pm 4$ & $266 \pm 5$ & $422 \pm 14$ & 307 \\
\hline $\mathbf{L L}$ & $336 \pm 5$ & $261 \pm 4$ & $274 \pm 2$ & $252 \pm 2$ & $346 \pm 8$ & $281 \pm 3$ & $213 \pm 4$ & $224 \pm 3$ & 274 \\
\hline \multicolumn{10}{|c|}{ Buffaloes } \\
\hline EL & $484 \pm 13$ & $514 \pm 11$ & $440 \pm 10$ & $530 \pm 12$ & $438 \pm 7$ & $348 \pm 9$ & $484 \pm 9$ & $429 \pm 11$ & 458 \\
\hline $\mathbf{L L}$ & $212 \pm 2$ & $238 \pm 2$ & $318 \pm 8$ & $310 \pm 6$ & $332 \pm 7$ & $317 \pm 4$ & $284 \pm 3$ & $274 \pm 2$ & 286 \\
\hline
\end{tabular}

*Means of measures of 10 alveoli in 12 microscopic fields. 
Table 7. Correlation coefficients between number (density) and volume of alveoli in parenchyma sections in udder samples of cattle breeds and buffaloes at early (EL) and late (LL) lactation in surface (SR) and middle (MR) regions of the four quarters (All are negative correlations)

\begin{tabular}{|c|c|c|c|c|c|c|c|c|}
\hline \multirow{3}{*}{ Breeds } & \multicolumn{4}{|c|}{ Fore quarters } & \multicolumn{4}{|c|}{ Rear quarters } \\
\hline & \multicolumn{2}{|c|}{ Right } & \multicolumn{2}{|c|}{ Left } & \multicolumn{2}{|c|}{ Right } & \multicolumn{2}{|c|}{ Left } \\
\hline & SR & MR & SR & MR & SR & MR & SR & MR \\
\hline \multicolumn{9}{|l|}{ Friesian } \\
\hline$\overline{\text { EL }}$ & $0.64 *$ & $0.85^{* *}$ & $0.86 * *$ & $0.78^{* *}$ & $0.61 *$ & $0.73 * *$ & $0.58^{*}$ & 0.35 \\
\hline LL & $0.91 * *$ & $0.85^{* *}$ & 0.46 & $0.71 * *$ & 0.60 * & $0.82 * *$ & $0.73 * *$ & 0.48 \\
\hline \multicolumn{9}{|l|}{$\underline{\text { E. Cattle }}$} \\
\hline EL & 0.33 & $0.71 * *$ & $0.87 * *$ & $0.98 * *$ & 0.41 & $0.63 *$ & $0.61 *$ & $0.96 * *$ \\
\hline LL & 0.35 & $0.82 * *$ & 0.46 & $0.60 *$ & 0.53 & $0.80 * *$ & $0.59 *$ & $0.64^{*}$ \\
\hline \multicolumn{9}{|l|}{ Buffaloes } \\
\hline EL & $0.83 * *$ & 0.31 & $0.70 * *$ & 0.25 & $0.82 * *$ & $0.72 * *$ & $0.79 * *$ & $0.73 * *$ \\
\hline LL & 0.34 & $0.88^{* *}$ & $0.81 * *$ & 0.53 & 0.22 & 0.43 & $0.83^{* *}$ & 0.51 \\
\hline
\end{tabular}

* Significant at $(\mathrm{P}<0.05) \quad * *$ Significant at $(\mathrm{P}<0.01)$.

Table 8. Alveoli parameters, general averages of density $\left(\mathrm{No} . / \mathrm{mm}^{2}\right)$ and size in the three species at early (EL) and late (LL) lactation

\begin{tabular}{lcccc}
\hline \multicolumn{1}{c}{ Parameter } & Lac. Stage & Friesian & E. Cattle & Buffaloes \\
\hline No. in mammary tissue & EL & 88 & 62 & 35 \\
& LL & 60 & 68 & 79 \\
No. in parenchyma & EL & 118 & 114 & 66 \\
& LL & 99 & 118 & 124 \\
Circumference $(\mu)$ & & & & \\
& EL & 316 & 307 & 458 \\
Diameter $(\mu)$ & LL & 317 & 274 & 286 \\
& & & & \\
Volume $\left(\mu^{\mathbf{3}}\right) \times \mathbf{1 0}^{\mathbf{4}}$ & EL & 101.6 & 99 & 151 \\
& LL & 101.2 & 89 & 91 \\
Surface area $\left(\boldsymbol{\mu}^{\mathbf{2}}\right) \times \mathbf{1 0}^{\mathbf{2}}$ & & & & 197 \\
& EL & 73 & 69 & 54 \\
& LL & 72 & 45 & 663 \\
& EL & 339 & 338 & 264 \\
\hline
\end{tabular}


It is clear in Table 8 that the size traits of Friesian alveoli were equal at (EL) and (LL) while that of buffaloes showed great reduction at (LL). Egyptian cattle had the smallest alveoli with clear shrinkage at late lactation stage.

The samples of the mammary tissue from the surface and middle regions of the quarters exhibited comparable values in the studied traits with few exceptional cases (Table 9). This result suggests that surface biopsy from animals at particular physiological status could demonstrate the general features of the gland.

Table 9. General averages of; parenchyma \% in sections of mammary tissue, number of alveoli $/ 1 \mathrm{~mm}^{2}$ and circumference of alveolus in surface (SR) and middle (MR) regions of the four quarters in udders of Friesian, E. cattle and buffaloes at early (EL) and late (LL) lactation

\begin{tabular}{|c|c|c|c|c|c|c|}
\hline \multirow[t]{2}{*}{ Breeds } & \multicolumn{2}{|c|}{ Parenchyma \% } & \multicolumn{2}{|c|}{$\begin{array}{l}\text { No. Alveoli/1 } \text { mm}^{2} \\
\text { in parenchyma }\end{array}$} & \multicolumn{2}{|c|}{ Circumference $(\mu)$} \\
\hline & SR & MR & SR & MR & SR & MR \\
\hline \multicolumn{7}{|l|}{ Friesian } \\
\hline$\overline{E L}$ & 70.9 & 70.8 & 80.9 & 94.7 & 277 & 355 \\
\hline $\mathbf{L L}$ & 68.9 & 80.8 & 62.6 & 57.4 & 319 & 315 \\
\hline \multicolumn{7}{|l|}{ E. Cattle } \\
\hline EL & 46.0 & 71.6 & 61.7 & 62.0 & 353 & 361 \\
\hline $\mathbf{L L}$ & 61.3 & 60.1 & 69.2 & 67.5 & 292 & 256 \\
\hline \multicolumn{7}{|c|}{ Buffaloes } \\
\hline EL & 87.7 & 73.3 & 30.7 & 37.8 & 462 & 455 \\
\hline $\mathbf{L L}$ & 69.6 & 79.2 & 81.5 & 76.9 & 287 & 286 \\
\hline
\end{tabular}

\section{REFERENCES}

Bychkov, N. P., 1971. Microscope structure of the udder in high-yielding cows at different stages of lactation. Dairy Sci. Abst., 33:2405.

El-Ghousien, Safaa. S., G. Ashour, M. M. Shafie, and A. L. Badreldin, 2002. Comparative study of the udder structure in buffaloes and cattle: 1Morphological and anatomical characteristics of the mammary gland. $53^{\text {rd }}$ Annual Meeting of the European Association for Animal Production, 1-4 September, 2002, Cairo, Egypt (Abstract).

Hassan, Laila R., 1994. Histological and chemical studies on the activity of the mammary gland in buffalo at successive stages of season of lactation. Ph. D. Thesis, Fac. Agric., Cairo Univ., Giza, Egypt.

Hassan, Laila R; G. Ashour; M.M. Shafie, and Lila H.Bedier, 1995a. Activity of mammary gland in buffaloes I- Histological and cytological characteristics. J. Agric. Sci., Mansoura Univ., Egypt, 20:2097-2110.

Hassan, Lila R; G. Ashour; Lila H.Bedier and M.M. Shafie, 1995b. Activity of mammary gland in buffaloes. II- Milk yield and composition. J. Agric. Sci., Mansoura Univ., Egypt, 20: 2111-2121.

Hunold, P., 1959. Histological examination of the udder in relation to milk production capacity. Dairy Sci. Abst., 22:2542. 
Krastev, H. and P. Konev, 1963. Histological examination of the udder of the Rhodope cattle. Abstr. Bulg. Sci. Lit., 8:56 (Dairy Sci. Abst., 26:1642).

Oshima, M. and T. Gota, 1955. Bull. Nat. Inst. Agric. Sci., Japan, 30:81.

Solov'eva, V.N., 1964. Structure of the mammary gland of Khamogar cows in relation to milk yield and fat content. Dokl Tinniryozev. Sel'skoz. Akad., Mosk. No. 104:13-21. (Dairy Sci. Abst., 29 (2) : 627).

Uppal, S.K., K.B. Singh, B.K. Bansal, D.C. Nariyal and K.S. Roy, 1995. Histomorphological study on the teat (mammary papilla) of Indian buffalo. Indian J. Anim. Sci., 65:853-856.

Wilde, CJ, C. V. P. Addey, P. Li and D. G. Fernig, 1997. Programmed cell death in bovine mammary tissue during lactation and involution. Experimental Physiology, 82:943-953. 


\section{دراسة مقارنة لتركيب الضرع في الجاموس والأبقار ؟ - التركيب الهستولوجي للغذة اللبنية}

صفاء سعيد الغصين'، محمد محمود الثافعي'، جمال عاشور ' وعبد اللطيف بدر الاين'

1 - كلية الزراعة والعلوم' جامعة جرش الأهلية، جرش، الأردن ، r - قسم الإنتاج الحيواني، جامعة القاهرة،

استخدم في هده الدراسة ستة ضروع، اثثان من كل من الجاموس والابقار المصرية والفريزيان أحدها في

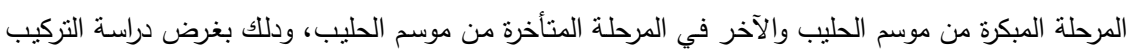

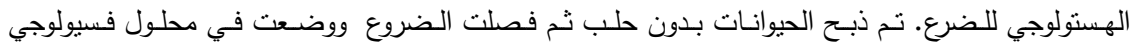

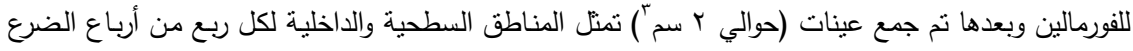

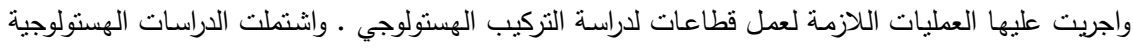

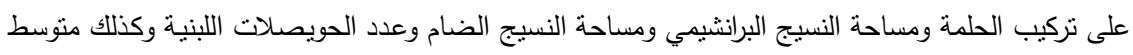

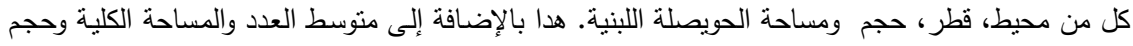

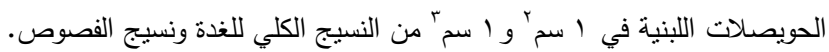
وأتضح من الدراسة ان الحلمة (القناة والعضلات) لها نفس التركيب العام في كل الحيوانات وكانت النسبة

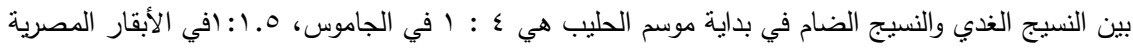

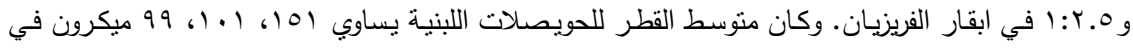

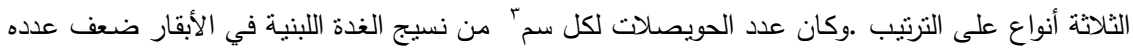

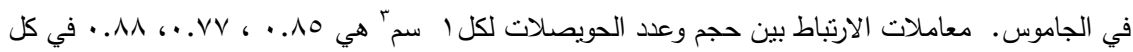

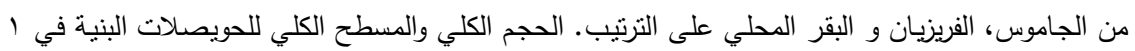

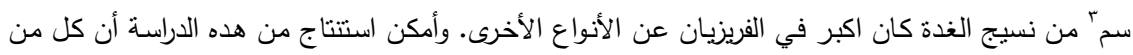

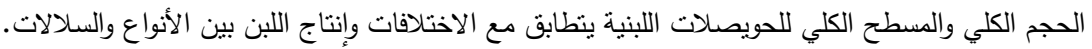

